\title{
Misi dalam Gereja Anabaptis Abad XVI: Tinjauan dari Perspektif Paradigma Misi Menurut David J. Bosch
}

\author{
Teguh Nugroho ${ }^{a, 1}$ \\ Fakultas Teologi Universitas Sanata Dharma, Yogyakarta, Indonesia ${ }^{a}$ \\ teguhnugroho367@gmail.com ${ }^{1}$
}

\section{KEYWORDS :}

Anabaptis, misi, radikal, Mennonite, pacifis, nirkekerasan, David J. Bosch

\begin{abstract}
The Anabaptist movement first appeared in the context of the church reform carried out by Martin Luther in the sixteenth century in Europe. The Anabaptist movement aimed at renewing the church based on the Scriptures, because the reforms carried out by the reformers, Luther and Zwingli, were deemed less fundamental. They still practice some of the rules and teachings of the Roman Catholic church, such as infant baptism and maintaining the relationship of the Church to the State. The Anabaptist movement rejected such practices. The Anabaptists tried to make reforms that were more radical than their predecessors. The Anabaptist group alone has about 1.7 million members worldwide today. The data raises the question of how they had a mission. The facts show that the Anabaptists were missionaries who were persistent in proclaiming their faith. The mission of the Anabaptists is based on three Anabaptist beliefs: Jesus is the center of faith, Mennonites are for peace, and community is at the center of life. These three beliefs will be analyzed using David J. Bosch's three paradigms to see the correlation between "Mission as the Mediator of Salvation" with the belief that Jesus is the center of faith, "Mission as Evangelism" with Mennonite beliefs that promote peace, and "Mission as Service by All God's People" with community as the center of life. The results of this analysis will show the radicalization of the Anabaptist movement.
\end{abstract}

\section{PENDAHULUAN}

Anabaptist adalah gerakan pembaharuan Gereja yang muncul pada masa Reformasi Martin Luther tahun 1517. Para ahli sejarah Anabaptist sekurangnya mempunyai dua teori mengenai asal-usul gerakan ini, yaitu monogenesis dan poligenesis.
Teori monogenesis mengatakan bahwa gerakan Anabaptis berasal dari peristiwa di Swiss yang dipelopori oleh Conrad Grebel dan rekan-rekannya pada tahun 1525. Pandangan kedua adalah poligenesis yang meyakini bahwa gerakan Anabaptis lahir bukan dari peristiwa tunggal, tetapi berasal dari beberapa kelompok yang 
berbeda. Sekurang-kurangnya ada tiga aliran kelompok yang melahirkan Anabaptis, yakni Swiss Anabaptism, Anabaptis Jerman Selatan/Austria, dan Anabaptis Jerman Utara/Belanda. Gerakan ini terjadi serentak dan saling berinteraksi selama 5 tahun, dari tahun 1525-1530. ${ }^{1}$ Anabaptis berasal dari dua kata "Ana" yang artinya "Ulang", dan "Baptis". Jadi, Anabaptis berarti "Baptis Ulang" atau "dibaptis Ulang". ${ }^{2}$ Nama Anabaptis sendiri merupakan julukan yang diberikan kepada kelompok ini oleh orangorang dari luar gerakan, meskipun demikian kelompok Anabaptis lebih memilih menyebut diri mereka sendiri dengan Persaudaraan atau Brethren. ${ }^{3}$

Gerakan ini tersebar di tiga wilayah Eropa, yakni: Swiss, Jerman Selatan dan Moravia, serta Jerman Utara dan Negerinegeri Belanda (Niederlande). Gerakan Anabaptis bersifat sporadis dan masingmasing wilayah memiliki corak yang berbedabeda. Meskipun gerakan ini beragam, tetapi mereka memiliki kesamaan dasariah dan keyakinan bersama. Sekurangnya ada tiga keyakinan bersama yang dimiliki kelompok ini: ${ }^{4}$ pertama, gerakan-gerakan ini diilhami oleh Roh Kudus. Kedua, konsekuensi dari Umat biasa yang membaca Alkitab, sehingga mereka menolak praktik-praktik yang tidak mereka temukan di sana. Ketiga, tanggapan terhadap gejolak perubahan sosial, ekonomi, dan politik yang melanda seluruh Eropa.
Daniel K. Listijabudi, Spiritualitas Anabaptis. (Semarang: Pustaka Muria, Sinode GKMI, 2018), 14.

2 Gerakan Anabaptist awal muncul di Zurich yang berasal dari para pengikut Ulrich Zwingli yang merupakan tokoh pembaharu gereja. Antara kelompok anak muda ini dengan Zwingli sendiri terjadi ketegangan akibat perbedaan pendapat mengenai reformasi.

Cornelius J. Dyck (Ed.), An Introducing To Mennonite History, Cetakan kesembilan (Scottdale: Herald Press, 1979), 36.

$4 \quad$ Stuart Murray, Anabaptis yang Telanjang: Hal-hal Hakiki yang Nyata dari Sebuah Iman yang Radikal (Semarang: Pustaka Muria, 2012), 160.
Kelompok Anabaptis menginginkan pembaharuan secara radikal berdasarkan Kitab Suci, karena mereka melihat reformasi yang dilakukan oleh Luther dan Zwingli kurang radikal. Kedua reformator ini masih mempraktikan Baptisan bayi dan keterlibatan negara di dalam urusan Gereja. ${ }^{5}$ Kelompok Anabaptis menolak hubungan antara Gereja dan negara, melarang orang Kristen mengangkat senjata, serta tidak membaptis bayi. Sebaliknya, mereka menekankan baptisan orang percaya. Perubahan hidup seseorang setelah pembaptisan menjadi hal penting, yakni orang percaya memiliki komitmen menjalani hidup patuh pada perintah Kristus. ${ }^{6}$ Selain itu, baptisan menjadi tanda bahwa orang-orang percaya mengikatkan diri pada disiplin gerejawi yang berlandaskan pada Matius 18: 15-18. ${ }^{7}$ Ayat ini dinilai menjadi petunjuk yang tepat untuk menjaga Gereja yang sejati. ${ }^{8}$ Bagi mereka, Gereja terdiri atas orang-orang percaya yang secara sukarela bergabung menjadi anggota. Negara tidak punya wewenang untuk memaksakan keanggotaan Gereja kepada setiap orang.

Kaum Anabaptis ini terus menyebarkan keyakinan-keyakinannya tersebut dengan giat, sehingga mereka menjadi ancaman untuk Gereja dan negara. Berbagai usaha

Radikal yang dimaksud adalah perubahan secara mendasar sesuai dengan yang tertulis dalam Kitab Suci. seringkali terjadi kesalahpahaman, arti kata radikal disamakan dengan gerakan kekerasan.

$6 \quad$ C. Arnold Snyder, Dari Benih Anabaptis: Intisari Kesejarahan Jati Diri Anabaptis, (Semarang: Pustaka Muria, 2007), 26.

Matius 18:15-18, "Apabila saudaramu berbuat dosa, tegorlah dia di bawah empat mata. Jika ia mendengarkan nasihatmu engkau telah mendapatnya kembali. Jika ia tidak mendengarkan engkau, bawalah seorang atau dua orang lagi, supaya atas keterangan dua atau tiga orang saksi, perkara itu tidak disangsikan. Jika ia tidak mau mendengarkan mereka, sampaikanlah soalnya kepada jemaat. Dan jika ia tidak mau juga mendengarkan jemaat, pandanglah dia sebagai seorang yang tidak mengenal Allah atau seorang pemungut cukai. Aku berkata kepadamu: Sesungguhnya apa yang kamu ikat di dunia ini akan terikat di sorga dan apa yang kamu lepaskan di dunia ini akan terlepas di sorga.

8 C. Arnold Snyder, Dari Benih Anabaptis: Intisari Kesejarahan Jati Diri Anabaptis, 32 
dilakukan untuk memadamkan gerakan ini. Penganiayaan, pemenjaraan, bahkan hukuman mati adalah cara yang digunakan negara dan Gereja. Semua ketentuan ini tidak menyurutkan semangat kaum Anabaptis untuk terus menyebarkan imannya. Sikap hidup dan usaha misi yang mereka lakukan menjadi daya pikat banyak orang untuk bergabung di dalamnya. Komunitas Anabaptis memiliki tiga nilai pokok yang dihidupi: Yesus Sebagai Pusat Iman, orang kristen selalu mengedapankan perdamaian, dan komunitas sebagai pusat kehidupan. ${ }^{9}$ Ketiganya juga menjadi sumber penggerak misi Anabaptis-Mennonite.

Yesus Kristus adalah pusat iman merupakan nilai inti yang dihidupi oleh kaum Anabaptis. mereka meledani kehidupan Yesus Kristus selama pelayanannya di bumi dan dipraktikan setiap hari dalam kehidupan. Becker meringkaskan nilai inti ini menjadi tiga: Mengikuti Yesus dalam kehidupan setiap hari, menafsirkan Kitab Suci di dalam terang Roh Yesus Kristus, dan berjanji untuk memberikan kesetiaan tertinggi kepada Yesus Kristus. ${ }^{10}$

Nilai inti kedua adalah komunitas adalah pusat kehidupan. Kaum Anabaptis memandang komunitas memiliki makna penting. Komunitas menjadi tempat bagi orang-orang percaya mempraktikkan pengampunan sebagai hal mendasar bagi komunitas, dialog dan belajar menafsirkan Kitab Suci bersama, dan komunitas terdiri atas kelompok-kelompok kecil yang saling mengenal, sehingga di dalamnya terjadi ikatan yang kuat. ${ }^{11}$

\footnotetext{
Palmer Becker, "What is an Anabaptist Christian?" Misio Dei $18,2$.

10 Palmer Becker, "What is an Anabaptist Christian?" Misio Dei 18, 8.

11 Palmer Becker, "What is an Anabaptist Christian?" Misio Dei $18,13$.
}

Rekonsiliasi sebagai pusat karya menjadi nilai inti ketiga bagi komunitas Anabaptis. Dasar karya rekonsiliasi adalah Allah mengirimkan Yesus Kristus untuk menebus dosa-dosa manusia. kaum Anabaptis percaya bahwa mereka telah diperdamaiakan dengan Allah. Tindakan Allah ini berimplikasi kaum Anabaptis dipanggil untuk menjadi agen-agen rekonsiliasi. Mereka membantu merekonsiliasi manusia kepada Allah, manusia kepada sesama dan menjadi utusan perdamaian di dalam dunia. Rekonsiliasi ini bertujuan membawa kepada transformasi kehidupan manusia dan dunia. ${ }^{12}$

Dalam perkembangannya, Gerakan Anabaptis terbagi dalam empat faksi, yakni Kelompok Mennonite, Amish, Hutterite, dan beberapa Kelompok Brethren. ${ }^{13}$ Tulisan ini akan membahas kelompok Anabaptismennonite (AM). Kelompok ini mulanya tersebar di berbagai wilayah yang pada akhirnya berhasil disatukan di bawah kepemimpinan Menno Simons sekitar tahun 1537. ${ }^{14}$ Mereka kemudian disebut Mennonite yang diambil dari nama pemimpinnya. Kelompok Mennonite berkembang di Belanda dan konsisten melakukan misi bahkan sampai ke luar Eropa.

Karya misi Mennonite Belanda meluas sampai di Indonesia. Mereka memiliki lembaga misi bernama $\mathrm{DZV}^{15}$ yang telah mengirimkan misionaris pertamanya bernama Pieter Jansz untuk menjalankan misi di Indonesia pada tahun 1851. Daerah utama misi mereka ialah pantai utara Jawa

\footnotetext{
12 Palmer Becker, "What is an Anabaptist Christian?" Misio Dei $18,18$.

13 Arnold C. Snyder, Anabaptist History and Theology: An Introduction (Kitcher, Ontario: Pandora Press, 1995), 1.

14 William R. Estep, The Anabaptist Story (Grand Rapids, Michigan: William B. Eerdmans Publishing Company, 1975), 121.

15 Doopsgezinde Zendings Vereeniging (DZV) didirikan pada tahun 1847 oleh jemaat-jemaat mennonite Belanda.
} 
Tengah, tepatnya di semenanjung Jepara dan sekitarnya. Misionaris Mennonite berhasil membentuk jemaat di tempat ini. Tempat pelayanan pertama Jansz adalah di desa Cumbring sekitar tahun 1852. ${ }^{16}$ Ada tiga sinode Gereja yang beraliran AnabaptisMennonite, yakni GKMI, GITJ, dan JKI. Ada satu Gereja lain di Indonesia yang merupakan hasil karya zending Mennonite Belanda, yaitu Gereja Kristen Protestan Angkola (GKPA) di komunitas Pakantan, Sumatera Utara. ${ }^{17}$ Gereja ini kemudian diserahkan kepada misi Lutheran.

Dalam artikel ini, penulis akan melihat ke-radikal-an dan korelasi misi AnabaptisMennonite (AM) di dunia abad ke-16 dan di Indonesia abad ke-19 dengan paradigma misi David J. Bosch. ${ }^{18}$ Paradigma misi Bosch yang akan digunakan ialah Misi sebagai Perantara Keselamatan, Misi sebagai Penginjilan, dan Misi sebagai Pelayanan oleh Seluruh Umat Allah. Hasil analisa ini nantinya akan menunjukan apakah Misi sebagai Perantara Keselamatan memiliki korelasi dengan keyakinan akan Yesus yang menjadi pusat iman; Misi sebagai Penginjilan memiliki korelasi dengan keyakinan Mennonit yang mengedepankan perdamaian; dan Misi sebagai Pelayanan oleh Seluruh Umat Allah memiliki korelasi dengan komunitas sebagai pusat kehidupan.

\section{DAVID J. BOSCH ${ }^{19}$}

David J. Bosch lahir pada tanggal 13 Desember 1929 di kota Kuruman, Provinsi Northern Cape, Afrika Selatan. Dia lahir dalam keluarga petani Afrikaner. ${ }^{20}$ Kedua orang tuanya merupakan anggota Gereja Reformed Belanda (Dutch Reformed Church) yang setia. Bosch menerima pendidikan Kristen Nasionalis sejak dia masih kecil. Bosch kuliah di Fakultas pendidikan di Universitas Pretoria, Afrika selatan pada tahun 1948. Orang yang mempengaruhinya selama masa-masa studi adalah E.P. Groenewald, Oscar Cullman, ${ }^{21}$ dan Karl Barth. Pengaruh Cullmann tampak dalam pandangan Teologinya, sedangkan pengaruh Barth yang terlihat dalam usaha sistematika sebagai dasar teologi bagi misi.

Pada tahun 1967, Bosch mengajar Sejarah Gereja dan Misiologi di Sekolah Teologi DRC di Decoligny, Transkei. Selama bekerja di tempat ini, Bosch menerbitkan disertasinya, menulis tiga buku pendek, menulis artikel, dan menjadi editor lima buku pengantar misiologi masyarakat Afrika Selatan. Bosch lewat tulisan-tulisannya mengkritik orang Afrika yang mendukung kebijakan apartheid. Akibatnya dia diasingkan dari DRC (Dutch Reformed Church). Pada tahun 1972, Bosch menerima undangan sebagai profesor Misiologi di Universitas Afrika Selatan (UNISA/University of South Afrika).

19 Riwayat David J. Bocsh disarikan dari http://www. internationalbulletin.org/issues/1999-01/1999-01-026livingston.pdf diunduh pada 20 April 2021.

20 Istilah Afrikaner merupakan sebutan khusus bagi orang Afrika Selatan kulit putih keturunan Belanda. Bangsa Belanda datang di Afrika pada tahun 1652 di Kota Cape yang menjadi koloni Belanda pada awal kedatangannya. Bagi orang-orang kulit putih keturunan inggris tidak disebut Afrikaner.

21 Oscar Cullmannn lahir di Straussburg, Jerman pada tahun 1902. Pada tahun 1930, Cullmann memperoleh penghargaan sebagai profesor Perjanjian Baru. Dia mengajar teologi di Paris kemudian mengajar di Basel. Cullmann merupakan orang yang produktif menulis buku. Di antara buku-bukunya, yaitu "The Christology of New Testament", "The Johannine Circle", "Jesus and The Revolutionaries" dan sebagainya. 
Baginya UNISA merupakan kampus yang unik dan menarik. Kampus ini merupakan kampus akademik apartheid, tetapi para staf dan mahasiswanya berasal dari berbagai suku. Dia mengajar di UNISA sampai akhir hidupnya. Dia meninggal dalam suatu kecelakaan lalu lintas pada tanggal 15 April 1992 di Afrika Selatan.

David Bosch memperkenalkan 13 paradigma tentang misi, yaitu: (1) Misi sebagai Gereja-dengan-yang lainnya, (2) Misi sebagai Missio Dei, (3) Misi sebagai perantara keselamatan, Misi sebagai perjuangan demi keadilan, (5) Misi sebagai penginjilan, (6) Misi sebagai kontekstualisasi, (7) Misi sebagai pembebasan, (8) Misi sebagai inkulturasi, (9) Misi sebagai kesaksian bersama, (10) Misi sebagai pelayanan oleh seluruh Umat Allah, (11) Misi sebagai kesaksian kepada orang-orang berkepercayaan lain, (12) Misi sebagai teologi, (13) Misi sebagai aksi di dalam pengharapan. Menurut penulis, dari kesemuanya itu, ada 3 paradigma yang terkait dengan dinamika perkembangan Gereja Mennonite, yaitu: Misi sebagai perantara keselamatan, Misi sebagai penginjilan, dan Misi sebagai pelayanan oleh seluruh Umat Allah. Ketiga paradigma ini dipilih karena memiliki relevansi dengan tiga nilai pokok yang dihidupi oleh kaum Anabaptis: Yesus Sebagai Pusat Iman, orang kristen selalu mengedapankan perdamaian, dan komunitas sebagai pusat kehidupan.

\section{MISI SEBAGAI PERANTARA KESELAMATAN}

Keselamatan adalah suatu keprihatinan dasariah dari setiap agama. ${ }^{22}$ Orang Kristen

\footnotetext{
22 David J. Bosch, Transforming Mission: Paradigm Shifts in Theology of Mission, 393
}

berkeyakinan bahwa Allah telah mengerjakan keselamatan bagi semua orang di dalam dan melalui Yesus Kristus. Pemahaman ini menjadi pusat kehidupan orang-orang Kristen. Keyakinan ini menjadi dasar gerakan misioner Kristen yang dimotivasi oleh kehendak untuk memperantarai ${ }^{23}$ keselamatan bagi semua orang. Teologi misi tergantung pada teologi tentang keselamatan, sehingga cakupan keselamatan menentukan cakupan usaha misioner. Bosch memberikan penjelasan lebih lanjut bahwa keselamatan di dalam Kristus adalah keselamatan di dalam konteks masyarakat manusia dalam perjalanan menuju dunia utuh yang disembuhkan. ${ }^{24}$

Di masa sekarang ini, penafsiran tentang keselamatan yang bekerja di dalam kerangka kristologis yang komprehensif, yang membuat totus Christus (keseluruhan Kristus) meliputi: inkarnasi, kehidupanNya di dunia, kematian, kebangkitan dan parousia Kristus. Para misionaris sekarang ini menyampaikan keselamatan yang "komprehensif", "terpadu", "total", atau "universal" dan semakin diidentifikasikan sebagai maksud misi. Untuk membawa kepada perubahan yang lebih baik, orang Kristen berarti memperantarai keselamatan. Keprihatinan manusia adalah keselamatan, maka manusia tidak lagi menganggap dirinya maupun orang lain sebagai tawanan dari Yang Mahakuasa. Misi Gereja adalah menjadi suatu gerakan perlawanan terhadap setiap perwujudan fatalisme dan sikap masa bodoh. ${ }^{25}$

\footnotetext{
23 Saya menggunakan kata "memperantarai" karena memiliki makna yang lebih sesuai, yaitu "menjadi perantara pada".

24 David J. Bosch, Transforming Mission: Paradigm Shifts in Theology of Mission, 399.

25 David J. Bosch, Transforming Mission: Paradigm Shifts in Theology of Mission, 399-400.
} 
Orang Kristen berpegang teguh pada keselamatan yang transenden, dan pada kebutuhan untuk memanggil orang-orang untuk percaya kepada Allah melalui Kristus. Keselamatan akan datang dalam perjalanan pertobatan dan komitmen iman pribadi. Keselamatan yang terpadu ini menuntut bahwa cakupan misi Gereja harus lebih komprehensif. Keselamatan itu koheren, luas, dan mendalam dengan kebutuhan dan tuntutan-tuntutan keberadaan manusia. Misi terlibat di dalam dialog terusmenerus dan berlangsung antara Allah dan dunia yang merindukan keselamatan. Keselamatan meliputi keselamatan jasmani dan rohani. Keselamatan telah terjadi, sedang berlangsung dan akan dipenuhi di masa mendatang.

\section{Yesus Menjadi Pusat Iman}

Paradigma Misi sebagai Perantara Keselamatan berakar dalam keyakinan bahwa Allah telah mengerjakan keselamatan bagi semua manusia di dalam dan melalui Yesus Kristus. Keyakinan seperti ini dihidupi oleh kaum Anabaptis abad keenam belas, di mana Yesus Kristus menjadi pusat Iman. Pengenalan akan Kristus secara mendalam terbentuk sebagai buah dari pembacaan Kitab Suci. Pada abad keenam belas, rakyat biasa, termasuk para petani, dapat memperoleh cetakan Kitab Suci dengan mudah. Mereka mengadakan pertemuan-pertemuan untuk membaca Kitab Suci bersama-sama. Zwingli pernah mengatakan bahwa rumah setiap petani menjadi sekolah pembacaan Kitab Perjanjian Lama dan Perjanjian Baru. ${ }^{26}$

Kaum Anabaptist sejalan dengan para reformator bahwa Alkitab adalah otoritas tertinggi bagi orang Kristen. Kaum Anabaptis

26 Hubert Jedin (Ed.), History of The Church Volume V (London: Burn \& Oates, 1980), 138. mengakuiperan Roh Kudus dalam pembacaan Kitab Suci. Gereja Protestan secara jelas menunjukan siapa yang berhak menafsirkan isi Alkitab, yaitu hanya para teolog terpelajar yang paling layak menafsirkan Alkitab. Sikap seperti ini berbeda dengan kaum Anabaptis yang lebih terbuka dalam hal menafsirkan Alkitab. Semua orang berhak menafsirkan Alkitab, baik orang terpelajar maupun tidak terpelajar, karena Roh Kudus akan memberikan pengertian kepada semua orang mengenai isi Firman Tuhan. ${ }^{27}$ Mereka mempelajari secara mendalam Kitab Perjanjian Baru, khususnya hidup dan ajaran-ajaran Yesus Kristus.

\section{Keselamatan Menyeluruh}

Orang Kristen diutus Allah untuk memberitakan keselamatan yang telah dikerjakan oleh Allah melalui dan di dalam Yesus Kristus kepada manusia untuk membawa kepada perubahan yang baik. Keselamatan ditafsirkan secara komprehensifmeliputiinkarnasi, kehidupanNya di dunia, kematrian, kebangkitan dan Parousia Yesus Kristus. Misi berarti diutus untuk memberitakan dalam perbuatan dan kata-kata bahwa Kristus hidup untuk mengubah hidup manusia dan mengalahkan maut, kristus mati dan bangkit untuk demi kehidupan dunia. ${ }^{28}$ Kesungguhan mengikuti Kristus terlihat pada keberanian melakukan penolakan terhadap praktek-praktek Gerejawi yang tidak sesuai ajaran Kitab Suci. Mereka tidak setuju dengan sistem Gereja-Negara. Kaum Anabaptis-Mennonite mengambil sikap taat kepada Firman Tuhan, yaitu sikap nirkekerasan dan pacifis. Istilah "pacifis" berasal dari bahasa Latin pax dan Ficare yang berarti membuat/menciptakan

\footnotetext{
C. Arnold Snyder, Dari Benih Anabaptis: Intisari Kesejarahan Jati Diri Anabaptis ( Semarang: Pustaka Muria, 2007), 5.

28 David J. Bosch, Transforming Mission: Paradigm Shifts in Theology of Mission, 400.
} 
perdamaian. ${ }^{29}$ Semangat ini diteladani dari Yesus Kristus yang mengajarkan kepada murid-muridnya untuk tidak melakukan kekerasan dan mengutamakan perdamaian. Mereka memilih taat kepada Allah daripada kepada pemerintah dunia.

\section{Anabaptis Swiss}

Kelompok Anabaptis bukanlah orangorang yang berdiam diri ketika melihat penyimpangan terhadap ajaran kekristenan, melainkan mereka secara berani meluruskannya. Tindakan itu tercermin dalam sikap mereka yang berani melawan aturan yang dibuat oleh penguasa. Pejabat pemerintah melarang adanya gerakan Anabaptis dan mengeluarkan aturan bahwa orang tua yang tidak mau membaptis bayinya dalam delapan hari akan diusir keluar dari kota Zurich dan wilayah Swiss. ${ }^{30}$ Semua itu tidak menghentikan kaum Anabaptis memberitakan Firman Tuhan. Mereka yang diusir keluar dari Zurich melakukan perjalanan ke berbagai daerah, menginjili, serta berbicara kepada saudara-saudara dan kenalan dengan harapan mereka mau menerimanya. ${ }^{31}$

Anabaptist Swiss dikenal sebagai kelompok Alkitabiah. Pertemuan-pertemuan rutin yang banyak menelaah Kitab Suci, terutama Kitab Perjanjian Baru, terus dilakukan. Mereka tidak menemukan dasar Kitab Suci mengenai perintah membaptis bayi. Baptisan diperuntukan bagi orang yang mengaku percaya kepada Yesus Kristus, karena baptisan adalah suatu tanda pertobatan dan masuk ke dalam persekutuan orang percaya. Oleh karena itu, baptisan

29 Daniel K. Listijabudi, "Bianglala Kemuridan Mennonite", 16.

30 Philip Schaff, History of the Christian Church, Volume VIII: Modern Christianity. The Swiss Reformation, 55.

31 Johnn A. Lapp dan C. Arnold Snyder. ( ed.), Testing Faith and Tradition (Kitchener, Ontari0: Pandora Press, 2006), 9. yang benar adalah baptisan orang percaya. Implikasi baptisan dewasa ialah, bahwa Gereja terdiri atas orang-orang percaya yang secara suka rela masuk ke dalamnya. Iman ini terus disebarkan ke banyak orang.

Eberli Bolt adalah martir pertama yang dibakar hidup-hidup pada tiang pancang pada 29 Mei 1525. Kotbah-kotbah Bolt mampu menarik sebanyak seribu lima ratus orang menjadi Anabaptis di wilayah Appenzell. ${ }^{32}$ Kurang dari setahun Appenzell menjadi kota Anabaptis. Tokoh lain adalah Felix Mantz. Sebelum dihukum mati dengan cara ditenggelamkan di sungai Limmat, Felix Mantz memberikan nasihat dan penghiburan kepada para pengikutnya supaya bertahan dalam iman kepada Yesus. ${ }^{33}$ Keberanian seperti ini bukan hanya dimiliki oleh para pemimpinnya, tetapi kaum Anabaptis umumnya. Sejarah mengenal kisah delapan belas orang Anabaptis yang dibakar hidup-hidup atas perintah Kardinal Matthaus Lang dari Salzburg pada tahun 1528. Mereka meninggalkan tulisan yang menguatkan orang-orang Anabaptis yang lain dalam menghadapi penganiayaan. Isi tulisan tersebut mengutip ayat dari Kisah Para Rasul 16:25 dan 1 Korintus 8: $6 .{ }^{34}$ Pada Minggu Paskah tahun 1525, baptisan ulang terjadi bersamaan di dua tempat berbeda. Pembaptisan dua ratus orang dilangsungkan di sebuah sungai di kota St. Gall dan tiga ratus orang di Waldsut, perbatasan SwissAustria. ${ }^{35}$

\footnotetext{
$32 \quad$ Kottelin-Longley, M. "What shall I do? The more I kill the greater becomes their number!": the suppression of Anabaptism in early sixteenth century. Scripta Instituti Donneriani Aboensis, 19 (2006): 185 [jurnal online]; tersedia dari https:// journal.fi/scripta/article/view/67308; diakses 8 April 2021.

33 Thieleman J. van Braght, The Bloody Theater or Martyr Mirror of The defenseless Christians [E-Book] (Grand Rapids, MI: Christian Classics Ethereal Library, 1660, 769)

34 Thieleman J. van Braght, The Bloody Theater or Martyr Mirror of The defenseless Christians, 790-791.

35 M. Kottelin-Longley, "What shall I do? The more I kill the greater becomes their number!": the suppression of Anabaptism in early sixteenth century. Scripta Instituti Donneriani
} 


\section{Anabaptist Jerman Selatan dan Hutterite}

Kelompok Anabaptist di Jerman Selatan dan Moravia dipengaruhi kuat oleh mistik abad pertengahan, sikap anti klerus dan pengharapan apokaliptik. Kesalehan pribadi sangat diutamakan dalam kelompok ini. Kehidupan batin dan pengalaman rohani seseorang sangat sangat penting. Semua unsur itu bercampur dan menjadi dasar yang mendorong transformasi tatanan sosial ke arah yang baik. ${ }^{36}$

Pengaruh mistik menuntun setiap anggotanya memiliki kehidupan rohani yang baik dan saleh. Kesalehan hidup pribadi yang berdampak pada perubahan masyarakat. Ide hidup baru menjadi pusat teologi. Kesalehan hidup dipersiapkan guna menyambut kedatangan Kristus kedua. Firman Tuhan dihayati dalam kehidupan yang ditunjukkan dalam memberitakan Firman Tuhan dengan berkhotbah keliling, membaptis orang percaya, sikap pasifis, dan memisahkan urusan Gereja dan negara.

Kelompok Hutterit ${ }^{37}$ dipengaruhi kuat oleh pandangan Eskatologi. Mereka menantikan kedatangan Kristus kedua, sehingga kekayaan apapun tidak berguna. Doktrin ini berdampak pada semangat persaudaraan dan egalitarian yang terwujud dalam kepemilikan bersama. Produksi dilakukan oleh komunitas dan hasilnya digunakan bersama. Mereka mempunyai etos kerja tinggi, maka mereka memiliki industri yang maju dan

Aboensis 19 (2006): 184 [jurnal online]; tersedia dari https:// journal.fi/scripta/article/view/67308; diakses 8 April 2021.

36 J. Denny Weaver, Becoming Anabaptist, (Scottdale: Herald Press, 1987), 52.

37 Satu tahun kemudian dua kelompok Anabaptist dari kota Tyrol dan Auspitz yang dipimpin oleh Yakob Hutter mengungsi ke Auterlitz. Kelompok-kelompok ini kemudian membentuk konfederasi. Seiring berjalannya waktu, Yakob Hutter diangkat menjadi pemimpin. Kelompok ini kemudian disebut Hutterite yang diambil dari nama Hutter. hidup makmur. Walaupun mereka lebih mengutamakan kehidupan komunitas, kaum ini memiliki semangat tinggi untuk misi di daerah lain. Kelompok ini banyak mengirim para misionaris ke daerahdaerah Eropa lainnya. ${ }^{38}$ Para misionaris ini menyebarkan Injil, memanggil orangorang untuk bertobat dan mengubah hidup mereka dalam semangat lahir baru, serta mengundang semua orang mengikuti Yesus untuk menjadi murid yang sejati. ${ }^{39}$ Jadi, dari sini dapat dipahami bahwa penekanan utama misi bukan pada penambahan jumlah anggota, tetapi lebih kepada transformasi kehidupan.

\section{Anabaptis Jerman Utara dan Belanda/ Niederlande $^{40}$}

Melchior Hoffman adalah seorang tokoh penting bagi Anabaptis di Belanda pada abad keenam belas. Ia anti pejabat gerejawi dan dengan berani menyuarakan pesan keadilan sosial. Inilah yang membuatnya populer di antara kaum miskin. ${ }^{41}$ Hoffman berkeliling ke berbagai daerah, antara lain Emden, Friesland timur, untuk mengkhotbahkan kedatangan Kristus kedua kali dan Baptisan sebagai bentuk ikatan perjanjian antara Kristus dan manusia. Orang-orang yang mendengarkan khotbahnya menjadi percaya dan dibaptis. Dia membaptis hampir tiga ratus orang di kota Emden pada bulan Juni 1530. Ia mempublikasikan sejumlah tulisannya yang berisi gagasan tentang akhir zaman, nubuatnya, dan eskatologi Kitab Suci.

\footnotetext{
38 Cornelius J. Dyck (Ed.), An Introducing To Mennonite History, 56.

39 https://gameo.org/index.php?title=Hutterite_Missioners_ (Sendboten); diunduh pada 15 Juli 2021.

$40 \quad$ Niederlande atau negara Belanda saat ini. J. Denny Weaver dalam buku Becoming Anabaptist menggunakan Low countries untuk menyebut Niederlande. Wilayah Low countries terdiri atas negara Belgia, Luxemburg, dan Belanda. Wilayah ini berbatasan dengan Jerman di sebelah timur dan sebelah selatan dengan Perancis. https://www.britannica.com/place/ Low-Countries; diakses pada 8 April 2021.

${ }_{41}$ Stuart Murray, Anabaptis yang Telanjang, Terjemahan, 174.
} 
Hoffman memberitakan imannya dengan cara berkhotbah keliling dan membaptis; dan itu diikuti oleh para pengikutnya. ${ }^{42}$

Salah satu kelompok Hoffman berada di bawah kepemimpinan Obbe Philips, Dirk Philips, dan Menno Simmons. Kelompok ini mengedepankan nonkekerasan dan jalan damai. Dalam perkembangan selanjutnya, Menno Simons diangkat oleh jemaat untuk menjadi pemimpin mereka. Menno mengunjungi dan mengumpulkan kelompokkelompok anabaptis yang tercerai berai dari Niederlande (Belanda) sampai Delta Vistula (Polandia). Ia banyak berkhotbah dan membaptis orang-orang yang bertobat. Di luar itu, Menno menulis buku dan tulisantulisan sebagai bahan ajar dan memelihara iman jemaat. ${ }^{43}$

\section{Misi Mennonit di Indonesia}

Gereja-gereja Anabaptis-Mennonite, GKMI dan GITJ, di Indonesia memiliki keterikatan dengan Gereja Mennonite Belanda. Pieter Jansz adalah misionaris Mennonite pertama yang datang ke Indonesia di bawah lembaga misi Mennonite bernama DZV (Doopsgezinde Zending Vereeniging) tahun 1851. Karya misi yang dilakukan oleh Jansz adalah berkhotbah dan mengajar agama kepada orang-orang Jawa. Jansz memilih pembantu penginjil dari beberapa orang Jawa, seperti Andreas Ngariman, Tresna, dan Pasrah Karso. Mereka ialah merintis jemaat dan mengajarkan iman Kristen kepada penduduk di sekitar semenanjung Jepara. ${ }^{44}$ Orang-orang yang menerima Injil kemudian dibaptis. Pada hari paskah tanggal 16 April 1854, Jansz membaptis lima orang Jawa untuk

\footnotetext{
J. Denny Weaver, Becoming Anabaptist, 79

43 J. Denny Weaver, Becoming Anabaptist, 103.

44 Pemerintah Hindia Belanda sudah memetakan daerah-daerah misi di Hindia Belanda/ Indonesia saat ini. Misi Mennonite mendapat tempat di wilayah pantai utara Jawa, tepatnya di sekitar semenanjung Jepara.
}

pertama kalinya. Mereka adalah Dja Santika, mBok Setro, Dimah, Rasinah (nyai Sieber), dan Janiah (ni Polok). Perjamuan Kudus juga dilakukan setelah upacara baptisan. ${ }^{45}$

Misionaris Mennonite lain yang juga rekan Jansz adalah H.C. Klinkert. Ia tiba di Jawa lima tahun setelah Jansz. Ia lebih banyak memfokuskan pelayanan misi dalam bidang literatur dengan menjadi anggota Lembaga Alkitab. Klinkert menterjemahan Alkitab ke dalam bahasa Melayu, karena memang waktu itu terjemahan Alkitab yang ada masih banyak kekurangan. Tujuan penterjemahan Alkitab adalah untuk bahan bacaan anak sekolah dan menginjili orang-orang Muslim. Salah satu naskah yang diterjemahkan oleh Klinkert adalah kisah Yusuf. Kisah ini dipilih karena tokoh Yusuf merupakan salah satu tokoh yang diagungkan oleh orang-orang Muslim. ${ }^{46}$

\section{Gereja Kristen Muria Indonesia (GKMI) ${ }^{47}$}

GKMI bermula dari seorang pengusaha Tionghoa dari kota Kudus bernama Tee Siem Tat. Dia sebelumnya tidak beragama Kristen. Suatu ketika Tee mengalami sakit, dia sudah berobat ke dokter, dukun, kongcokongco (dewa-dewa atau orang suci) di klenteng-klenteng tetapi belum sembuh. Usaha lain yang diambil ialah mengundang seorang guru agama Kristen bernama Tanuhatu ke rumahnya guna mendoakan kesembuhannya. Akhirnya Tee Siem Tat mengalami kesembuhan secara ajaib. Peristiwa ini membawanya percaya kepada Yesus Kristus dan menjadi Kristen, bahkan ia semakin serius mempelajari agama Kristen.

\footnotetext{
45 Sigit Heru Soekotjo dan Lawrence M. Yoder, Tata Injil di Bumi Muria: Sejarah Gereja Injili di Tanah Jawa-GITJ (Semarang: Pustaka Muria, 2010), 132-133.

46 Alle Hoekema, Alle Hoekema, Globalisasi Misi Mulai Abad ke-19: Hubungan Gereja-gereja Mennonit di Negeri Belanda dengan Indonesia, (Semarang: SINODE GKMI, 2002), 71.

47 Yudha Lelana, Tunas Yang Tumbuh: Sejarah Gereja Kristen Muria Indonesia 1920-1977 (Semarang: SINODE GKMI, 2002).
} 
Pengalaman rohani Tee Siem Tat mendorongnya untuk memberitakan Injil Yesus Kristus kepada orang-orang Tionghoa lainnya yang berada di Kudus dan sekitarnya. Ikatan keluarga di antara keluarga Tionghoa peranakan/Kiauwseng menjadi cara efektif menyebarkan Injil. Keluarga yang sudah bertobat kemudian menyebarkan Injil kepada keluarga-keluarga yang lain. Tee Siem Tat dan kawan-kawannya dalam memberitakan Injil memakai bahasa dan cara yang sederhana sehingga mudah dimengerti. Orang-orang Tionghoa yang sudah menjadi kristen ini sering bertemu untuk membicarakan Firman Tuhan, serta memuji Tuhan dengan nyanyian dan doa. Mereka tidak hanya bersaksi dalam persekutuan saja, tetapi juga menceritakan imannya kepada orang-orang yang belum percaya Yesus Kristus, baik dari suku Tionghoa maupun suku Jawa. Alhasil ada sekelompok orang Jawa datang dan meminta untuk dibaptis.

Sinode GKMI memiliki lembagalembaga untuk memberitakan Injil, yakni PIPKA dan MDS. ${ }^{48}$ PIPKA fokus dalam membuka pos-pos pelayanan di luar pulau Jawa seperti Sumatera dan Kalimantan. Mereka menginjili orang-orang yang belum mengenal atau percaya kepada Yesus. Sekarang ini ada banyak jemaat atau Gereja di bawah naungan PIPKA. MDS bekerja sama dengan MCC dan Lembaga Perdamaian Lintas Agama dan Golongan (LPLAG) memberikan pelayanan kepada masyarakat luas di bidang penanggulangan bencana, perdamaian, perawatan lingkungan, dan jaringan kerja sama lintas iman. Saat ini, MDS mampu membangun jaringan dengan Corp Hizbullah "Batalyon 99" Divisi Sunan

\footnotetext{
8 Pengutusan Injil dan Pelayanan Kasih (PIPKA) merupakan badan misi Gereja Kristen Muria Indonesia yang dibentuk pada tanggal 15 Mei 1965. Mennonite Diakonia Service (MDS) didukung oleh Mennonite Central committee (MCC) dalam karya pelayanannya.
}

Bonang di Solo. MDS berdiri atas prakarsa Pendeta Paulus Hartono yang waktu itu melayani di GKMI Solo. Embrio MDS dimulai dari gerakan Mennonite Community dengan proyek percontohan GKMI Solo tahun 1995. ${ }^{49}$ Pada tahun 2005 diadakan pertemuan Sinode GKMI di Caringin, Bogor; dan Pdt. Paulus Hartono menyerukan supaya GKMI mengesahkan sebuah lembaga untuk memperluas pelayanan diakonia transformatif yang disebut Mennonite Diakonia Service (MDS). ${ }^{50}$ Selanjutnya pada tahun 2009, MDS dicatatkan dalam akta notaris dan menjadi lembaga baru yang menjadi mitra GKMI dan berkantor di komplek Mennonite Training Center (MTC), Salatiga.

\section{MISI SEBAGAI PENGINJILAN 51}

Misi sebagai penginjilan berarti memberitakan Firman Tuhan melalui perbuatan, teladan, "kehadiran kristiani", dan kesaksian dari orang-orang kristen sendiri. Tindakan-tindakan itu disebut dengan penginjilan. Injil adalah "Firman yang menjadi Daging". Oleh karena itu, Pengejawantahan Injil diperlukan untuk memperkenalkan Allah kepada orang-orang lain. Kesaksian dan pelayanan adalah sarana untuk mengkomunikasikan Injil kepada khalayak umum.

Bosch memberikan kesimpulan bahwa penginjilan adalah dimensi dan aktivitas misi Gereja yang menawarkan kepada setiap orang dan komunitas suatu kesempatan yang sahih untuk secara langsung melakukan re-

\footnotetext{
49 Agus Suyanto dan Paulus Hartono, Laskar dan Mennonite: Perjumpaan Islam-Kristen untuk Perdamaian di Indonesia. (Jakarta: BPK Gunung Mulia, 2016), 4

50 Agus Suyanto dan Paulus Hartono, Laskar dan Mennonite: Perjumpaan Islam-Kristen untuk Perdamaian di Indonesia,24.

51 Disarikan dari buku David J. Bosch, Transforming Mission: Paradigm Shifts in Theology of Mission, 409-420.
} 
orientasi yang radikal dalam hidup mereka. Ini merupakan suatu re-orientasi yang melibatkan hal-hal seperti pembebasan dari perbudakan oleh dunia dan kuasa-kuasanya, merangkul Kristus sebagai Juruselamat dan Tuhan, menjadikan anggota yang hidup dari komunitas Gereja dilibatkan dalam pelayanan, perdamaian, dan keadilan-Nya di dunia; dan mengikatkan diri dengan maksud Allah yang meletakkan segala sesuatu di bawah pemerintahan Kristus. ${ }^{52}$

\section{Peran serta dalam Bidang Sosial}

Kaum Anabaptis awal adalah kelompok keagamaan yang terlibat aktif dalam pergerakan sosial yang turut mengusahakan pembaharuan Gereja dan masyarakat. Mereka memperjuangkan hak-hak kelompok masyarakat kelas bawah. Christoph Schappeler menyampaikan beberapa tuntutan petani, yakni kebebasan memilih pendeta lokal, kotbah yang murni sesuai Kitab Suci, menggunakan perpuluhan untuk gaji para pastor, penghapusan penggunaan perpuluhan untuk hal-hal yang tidak perlu, penghapusan perbudakan sebab Kristus datang menebus semua orang dan mereka akan dibebaskan, dan penghapusan hak-hak khusus yang berhubungan dengan perburuan serta penangkapan ikan. ${ }^{53}$ Beberapa orang dari kaum Anabaptis Jerman terlibat dalam gerakan perang petani, seperti Thomas Muntzer. ${ }^{54}$

\section{Mengikuti Teladan Yesus Kristus}

Tuhan Yesus adalah teladan iman yang diikuti oleh kaum Anabaptist. Hal ini terus dihayati dalam hidup pribadi dan komunitas. Cara mereka memberitakan

\footnotetext{
52 David J. Bosch, Transforming Mission: Paradigm Shifts in Theology of Mission, 420.

53 Erwin Iserloh, Joseph Glazik, dan Hubert Jedin, History of The Church Volume V, 141.

54 J. Denny Weaver, Becoming Anabaptist, 56.
}

Injil adlah lewat sikap hidup. Mereka selalu melakukan hal-hal baik dan peduli kepada orang-orang di sekitarnya. Kepedulian terhadap yang tertindas dan penolakan terhadap kekerasan terus digaungkan di dalam komunitas. Seorang Anabaptis dari Dordrecht bernama Joris Wipe adalah contohnya. Ia banyak memberi bantuan kepada orang-orang miskin dan dikenal sebagai orang yang baik. Pada tahun 1558, ia dijatuhi hukuman mati oleh penguasa kota, karena ketahuan menjadi anggota Anabaptis. Penguasa setempat enggan untuk menjatuhi hukuman kepadanya, karena sikap dan hubungan baik yang telah terjalin. Penguasa juga kesulitan mencari algojo yang bersedia untuk mengeksekusi. Profesi sebagai algojo bukan pekerjaan terhormat. Mereka pada umumnya berasal dari orangorang miskin. Gereja dan penguasa telah menghukum lebih dari empat ribu orang Anabaptis, tetapi mereka tidak membalas hal itu dengan perlawanan senjata. Sikap seperti ini menunjukkan bahwa kaum Anabaptis secara konsisten mengedepankan sikap pacifis/damai dan nirkekerasan.

\section{Pertemuan-pertemuan di Rumah Tangga}

Kelompok-kelompok Anabaptis sering mengadakan pertemuan di rumahrumah untuk mendiskusikan Kitab Suci. ${ }^{55}$ Kelompok-kelompok kecil ini merupakan cara efektif bagi mereka untuk berdiskusi secara intens mengenai isu-isu seputar Gereja dan masyarakat. Mereka merasa perlu pembaharuan terhadap Gereja seturut Kitab Suci. Kaum Anabaptis menolakaturan tentang membayar pajak dan perpuluhan. Mereka terus menyerukan suara pembaharuan lewat kotbah-kotbah maupun berbicara kepada orang-orang di sekitar. Mereka

\footnotetext{
55 Wilbert R. Shenk (ed.) Anabaptism and Mission (Scottdale: Herald Press, 1984), 56.
} 
adalah pengkhotbah yang militan dan berani, meskipun mendapat ancaman dari Gereja dan penguasa. Banyak di antara mereka yang dihukum mati dengan ditenggelamkan ke sungai, dipenggal kepalanya, dan dibakar hidup-hidup pada tiang pancang. Alihalih membuat takut, mereka memaknai penganiayaan yang terima sebagai bukti bahwa mereka menderita bersama Kristus.

\section{Bersaksi di Depan Publik}

Salah satu tempat efektif untuk memberitakan Injil kepada khalayak ramai ialah tempat eksekusi. Hukuman mati dilaksanakan di tempat-tempat umum supaya masyarakat takut menjadi anggota Anabaptis. Pemikiran seperti itu ternyata salah. Tempat eksekusi biasa didatangi oleh banyak orang, sehingga mereka memakai momentum ini sebagai kesempatan untuk bersaksi tentang imannya. Sebelum eksekusi dilangsungkan, mereka akan meneriakkan seruan untuk mengikuti ajaran Kitab Suci yang benar, menyampaikan iman mereka, menyanyikan pujian kepada Tuhan yang berisi ucapan syukur atau penguatan untuk orang-orang Anabaptis lainnya ${ }^{56}$ Cara untuk mencegah mereka tidak berbicara di depan umum ialah menyumbat mulut tahanan memakai bubuk mesiu sebelum dibakar hidup-hidup di tiang pancang seperti terjadi pada Anneken Hendriks ${ }^{57}$ atau di gembok lidahnya seperti Meyken Wens. ${ }^{58}$

\section{Di Indonesia}

Pelayanan misionaris di Indonesia tidak terbatas dalam lingkup Gerejawi, namun mencakup pelayanan kepada masyarakat luas. Ada lima bidang pelayanan kepada masyarakat luas.

Wilbert R. Shenk (ed.) Anabaptism and Mission, 57.

57 Thieleman J. van Braght, The Bloody Theater or Martyr Mirror of The defenseless Christians, 1608.

58 John S. Oyer dan Robert S. Kreider, Cermin Para Martir, (Semarang: Pustaka Muria, 1999), 53.
Pertama, menyediakan fasilitas kesehatan. Kedua, memperjuangkan hakhak dan keadilan bagi warga pribumi yang ditindas oleh penjajah. Sebagai misionaris Belanda, Jansz berani melawan pemerintah Hindia Belanda karena menindas rakyat pribumi. Ketiga, keberanian melawan peredaran opium yang didukung oleh pemeritah Hindia Belanda. Untuk mencegah peredaran candu, Jansz mengkoordinir orang-orang yang peduli akan masalah ini. Keempat, pelayanan dalam bidang pendidikan dengan mendirikan sekolah untuk misi maupun pendidikan umum bagi warga pribumi maupun Tionghoa. Kelima, upaya untuk mendirikan desa persil ${ }^{59}$ dan menerima siapa saja yang mau bergabung di dalamnya, termasuk orang yang tidak beragama Kristen asalkan mau mengikuti aturan-aturan yang dibuat. Sektor-sektor tersebut memang sangat dibutuhkan oleh masyarakat umum. Dana yang dibutuhkan untuk membiayai pelayan tersebut sangat besar, sehingga Jansz seringkali menggunakan uang pribadinya. ${ }^{60}$

\section{MISI SEBAGAI PELAYANAN OLEH SELURUH UMAT ALLAH}

Paradigma misi baru yang muncul ialah misi yang melibatkan seluruh umat Allah, baik rohaniwan maupun awam. Jikalau selama berabad-abad lalu rohaniwan dinilai menduduki tempat lebih tinggi daripada

\footnotetext{
$59 \quad$ Desa Persil adalah desa Kristen yang dibuat oleh P. A. Jansz dengan menyewa tanah perkebunan persil milik pemerintah Hindia Belanda. Tanah itu disewa oleh Jansz dalam jangka panjang selama 75 tahun. Penghuni desa ini berasal dari orangorang Kristen hasil penginjilan Jansz. Tujuan didirikan Desa Persil untuk menjadikan jemaat Kristen sebagai masyarakat yang teratur baik secara rohani dan jasmani. Penghuni desa Kristen bisa bebas dari pengaruh buruk masyarakat seperti pelacuran, perjuadian, dan percanduan. Mereka juga nantinya bekerja dengan mengelola tanah persil tersebut. Lih. Sigit Heru Soekotjo dan Lawrence M. Yoder, Tata Injil di Bumi Muria: Sejarah Gereja Injili di Tanah Jawa-GITJ, 182-184.

60 Sigit Heru Soekotjo dan Lawrence M. Yoder, Tata Injil di Bumi Muria: Sejarah Gereja Injili di Tanah Jawa-GITJ, 169-171.
} 
awam dalam misi, sekarang ini awam dan rohaniwan memiliki posisi setara. Zaman sudah berubah. Orang Kristen sudah mulai gerakan "kerasulan awam" atau "imamat orang percaya”. Para rohaniwan berperan menyertai kaum awam. Roh Perjanjian Baru telah diberikan kepada seluruh umat Allah, bukan hanya kepada orang-orang pilihan tertentu. Oleh karena itu, paguyuban menjadi pengemban utama misi. ${ }^{61}$

Suatu teologi tentang kaum awam dibutuhkan dalam situasi sekarang ini. Pelayanan mereka ditawarkan dalam bentuk kehidupan paguyuban Kristen yang berkelanjutan di dalam kehidupan mereka sehari-hari. Dalam kebanyakan kasus, pelayanan gabungan antara para rohaniwan dan kaum awamlah yang bekerja, sehingga pelayanan rohaniwan dan awam tidak terpisahkan. Para rohaniwan tidak melakukan misi sendirian, melainkan bersama-sama dengan seluruh umat Allah karena semua telah menerima Roh Kudus yang memimpin Gereja di dalam semua kebenaran. Rohaniwan dan kaum awam adalah Gereja yang diutus ke dalam dunia.

Pada bagian ini, penulis akan menunjukkan peranan rohaniwan, kaum awam dan perempuan dalam misi Anabaptis awal maupun pada zaman setelahnya. Perkembangan Anabaptis merupakan usaha bersama antara awam dan rohaniwan. Lembaga-lembaga misi dibentuk atas kerjasama antara rohaniwan dengan umat awam.

\section{Suatu Gerakan Awam}

Gerakan Anabaptis awal diinisiasi oleh kaum awam dari berbagai lapisan masyarakat dengan profesi yang beragam,

61 David J. Bosch, Transforming Mission: Paradigm Shifts in Theology of Mission, 472. seperti pedagang, perempuan, mantan Imam dan biarawan. Berikut akan diperlihatkan beberapa figur Anabaptist di tiga wilayah di Eropa. Para tokoh awam antara lain Conrad Grebel, Felix Manz, dan Simon Stumpf. Beberapa tokoh pemimpin kalangan adalah eks klerus, seperti George Blaurok seorang eks imam Katolik, Michael Sattler pernah menjadi prior di biara di Schwartzwald.

Tokoh-tokoh Anabaptist Jerman Selatan dan Moravia juga berasal dari kalangan awam dan rohaniwan. Mereka adalah Thomas Muntzer - sebelumnya seorang pendeta Lutheran dan pemimpin pemberontakan petani -, Hans Hut yang berprofesi sebagai penjual buku keliling, Hans Denck yang bekerja sebagai editor dan kemudian menjadi rektor di sekolah St. Sebald di Nuremberg, serta Pilgram Marpeck seorang kaya yang bekerja sebagai pegawai pertambangan. Kita juga mendapati nama-nama lain yang menjadi pemrakarsa penting Anabaptis di Moravia, yakni Balthasar Hubmaier sebelumnya pernah menjadi pendeta kampus di Regensburg, Widemann dan Philip Jager, Jakob Hutter yang pengaruhnya kuat terhadap Anabaptis.

Gerakan Anabaptist di Jerman Utara dan Niederlande terkait erat dengan tokoh yang bernama Melchior Hoffman. Ia seorang pedagang pakaian bulu yang terdidik. Sosok ini berhasil membaptis tokoh-tokoh penting lainnya, seperti Jan Volkertsz Tjipmaker, Jan Matthijs, Obbe Philips, dan Dirk Philips. Jan Matthijs adalah pengusaha roti dari Haarlem, Obbe Philips dan Dirk Philips merupakan mantan biarawan Katolik. Obbe kemudian membaptis Menno Simons yang awalnya seorang imam katolik. Kaum awam dan pemimpin membangun komunitas sebagai tempat untuk belajar Kitab Suci bersama. 
Kepemimpinan kelompok Anabaptis awal tidak harus dari kalangan sarjana teologi, tetapi juga orang awam ataupun bukan sarjana teologi. Orang-orang karismatik dan pelopor gerakan diangkat menjadi pemimpin oleh jemaat. Meskipun demikian, tugas dan tanggung jawab untuk memberitakan Injil Kristus diterima sebagai tugas bersama. Berkotbah, melayani perjamuan kudus, dan membaptis setiap orang yang percaya dilakukan oleh semua anggota. Pada bulan Februari 1525, Grebel dan Manz mendatangi rumah ke rumah untuk menyaksikan iman, membaptis, dan melangsungkan perjamuan kudus. ${ }^{62}$ Baptisan terjadi di banyak tempat di Eropa. Sebagian besar anggota Anabaptis aktif memberitakan imannya. Pertalian keluarga dan pertemanan dimanfaatkan untuk memberitakan iman dan mengajak bergabung. Usaha dan kegigihan mereka membuahkan hasil. Ada sekitar dua puluh lima persen populasi Niederlande Utara tergabung dalam kelompok Anabaptis Menno Simons. ${ }^{63}$

\section{Peran Perempuan dalam Gerakan Anabaptis}

Gerakan Anabaptis yang terus bertumbuh tidak bisa dilepaskan dari peran serta perempuan di dalamnya. Posisi mereka tidak dapat dikecilkan dalam konteks pelayanan semua umat Allah. Ada ratusan martir perempuan Anabaptis selama abad keenam belas. Kaum perempuan berpartisipasi dalam pemberontakan petani tahun $1525 .{ }^{64}$ Berikut akan diuraikan peran perempuan dalam gerakan Anabaptis di Swiss, Jerman Selatan-Moravia, dan Belanda.

\footnotetext{
$62 \quad$ William R. Estep, The Anabaptist Story, 27.

63 J. Denny Weaver, Becoming Anabaptist, 79.

64 Daniel K. Listijabudi, Spiritualitas Anabaptis (Semarang: Pustaka Muria, Sinode GKMI, 2018), 30.
}

Perempuan-perempuan Anabaptis Swiss muncul sebagai pemimpin informal yang aktif menyebarkan Anabaptisme. ${ }^{65}$ Mereka adalah perempuan berani, meskipun hukuman menanti bagi siapapun yang ketahuan menjadi anggota Anabaptis. Para perempuan ini terus menyampaikan ajaran Anabaptis secara rutin kepada perempuan dari anggota keluarganya, tetangga, dan kenalan. Margaret Hellwart, seorang perempuan Anabaptis Swiss, aktif mempengaruhi perempuan-perempuan lain untuk bergabung dengan gerakan Anabaptis. Tindakannya tidak bisa diabaikan. Bahkan penguasa setempat harus mengikatnya di rumah dengan rantai supaya tidak lagi bisa mempengaruhi orang lain. Cara itu tidak berhasil menghentikan Hellwart. Akhirnya, hukuman mati dijatuhkan kepadanya.

Anabaptis perempuan di Jerman Selatan dan Moravia unggul dalam mempengaruhi orang lain untuk bergabung dalam gerakan Anabaptis. Para perempuan ini menjadi pemimpin yang berpengaruh. Buah kegigihan mereka tampak dengan adanya banyak perempuan yang mau bergabung. Antara tahun 1527-1529, catatan pengadilan di Tyrol menunjukan bahwa ada sekitar dua ratus sepuluh orang perempuan Anabaptis yang dihukum. Jumlah itu sekitar empat puluh enam persen dari keseluruhan anggota yang diadili. ${ }^{66}$

Perempuan di lingkaran Anabaptist Belanda memiliki posisi berbeda. Melchior Hoffman perintis gerakan Anabaptis Belanda terbuka kepada pelayan perempuan. Ada sebagian perempuan Anabaptis lebih terdidik daripada kaum pria. Sebagai contoh

\footnotetext{
65 C. Arnold Snyder dan Linda A. Huebert Hecht (Eds.), Profiles of Anabaptist Women Sixteenth-Century Reforming Pioneers (Waterloo, Ontario: Wilfrid Laurier University Press, 1996), 21.

66 Snyder dan Hecht (Eds.), Profiles of Anabaptist Women Sixteenth-Century Reforming Pioneers, 75.
} 
adalah Margarethe Pruss dari Strasbourg. ${ }^{67}$ Dia menjadi pemilik percetakan. Usahanya ini memudahkannya untuk menyebarkan ide-ide Anabaptis secara luas dan cepat melalui tulisan-tulisan yang dicetak.

\section{Lembaga Misi Buah Karya Seluruh Umat}

Gereja Anabaptis-Mennonite

$(\mathrm{AM})$

Belanda mendirikan badan misi bernama DZV pada tahun 1847. DZV merupakan buah pikiran bersama antara jemaat Amsterdam, para pengusaha Mennonite dan profesor seminari di Amsterdam yang memiliki kepedulian terhadap misi. ${ }^{68}$ Misi Mennonite mengemban tugas misi dalam karya pendidikan, memajukan peradaban, dan penyebaran iman kristiani. Karya misi ini dikerjakan oleh Pieter Jansz sebagai misionaris DZV pertama di pulau Jawa. MCC sebuah lembaga pelayanan kristen yang didirikan oleh Gereja-Gereja Mennonite Amerika Utara tahun 1918. ${ }^{69}$ MCC bersama dengan MDS bergerak di bidang sosial, pendidikan, kesehatan, dan memberikan bantuan kepada korban bencana. ${ }^{70}$

\section{Kesaksian Keluarga Awam}

Berdirinya Gereja-Gereja Mennonite di Indonesia (GKMI, GITJ dan JKI) tidak bisa dilepaskan dari peran kaum awam. Pembahasan di sini akan fokus pada GKMI. GKMI dimulai dari pertobatan Tee Siem Tat. ${ }^{71}$ Tee adalah pengusaha Tionghoa di kota Kudus yang sebelumnya menganut agama leluhur. Ia disegani oleh orang-

67 Snyder dan Hecht (Eds.), Profiles of Anabaptist Women Sixteenth-Century Reforming Pioneers, 248.

68 Alle Hoekema, Globalisasi Misi Mulai Abad ke-19: Hubungan Gereja-gereja Mennonit di Negeri Belanda dengan Indonesia, 22-25.

69 https://gameo.org/index.php?title=Mennonite_Central_ Committee_(International) diakses pada 27 April 2021.

70 MCC adalah singkatan dari Mennoite Central Committee.

${ }_{71}$ Yudha Lelana, Tunas Yang Tumbuh: Sejarah Gereja Kristen Muria Indonesia 1920-1977 (Semarang: SINODE GKMI, 2002), 37. orang Tionghoa di Kudus dan sekitarnya. Pengalaman sembuh dari penyakit setelah didoakan oleh seorang pendeta Gereja Bala Keselamatan menjadi titik balik dalam hidupnya sekitar tahun 1917. Kesembuhan yang dinilai ajaib ini membawanya percaya Kepada Yesus Kristus. Pengalaman iman ini diceritakan kepada orang lain disekitarnya, bagaimana Yesus Kristus yang sudah menyembuhkan dirinya adalah Juruselamat umat manusia. Setelah Tee bertobat, ia dan Istrinya bersinergi dalam melakukan penginjilan ke berbagai tempat. Beberapa jam sebelum dimulai ibadah, keduanya mengunjungi dari rumah ke rumah untuk mengajak beribadah. Tee mendekati para kepala keluarga, sedangkan Sie mendekati dan mengajak para perempuan. ${ }^{72}$ Cara ini efektif menarik banyak orang, sekaligus mensiasati kebiasaan orang Tionghoa waktu itu tidak menginjinkan wanita keluar rumah, muncul di tempat umum, atau berbicara kepada lelaki lain yang bukan dari keluarga sendiri. Baru pada tahun pada tahun 1919 kelompok Kristen Tionghoa di Kudus mengadakan kontak dengan Misi Mennonit. Tee kemudian menjadi pendeta pertama Gereja Kristen Tionghoa, yang sekarang bernama GKMI.

Yudha Lelana menyebutkan enam faktor yang menentukan pertumbuhan Kristen Tionghoa di kota Kudus. ${ }^{73}$ Pertama ialah pengaruh Tee Siem Tat; kedua, penginjilan lewat garis-garis keluarga; ketiga, orangorang Tionghoa yang baru bertobat memiliki semangat dan dan gairah yang tinggi untuk memasyurkan Injil; keempat, Tee dan kawan-kawannya memberitakan Injil dalam bentuk dan bahasa yang sederhana, sehingga

\footnotetext{
72 Yudha Lelana, Tunas Yang Tumbuh: Sejarah Gereja Kristen Muria Indonesia 1920-1977, 81-82.

73 Yudha Lelana, Tunas Yang Tumbuh: Sejarah Gereja Kristen Muria Indonesia 1920-1977, 46-48.
} 
mudah diterima oleh orang-orang Tionghoa di daerah Muria; kelima, identitas kesukuan digunakan untuk mendekati dan mengajak orang Tionghoa datang kepada Kristus; dan keenam, banyak orang Kristen ambil bagian dalam gerakan penginjilan Kudus. Mereka semua yang terlibat dalam gerakan penginjilan adalah kaum awam yang tidak memperoleh pendidikan teologi.

Perempuan memiliki posisi penting bagi tonggak sejarah GKMI. Perempuan yang paling signifikan bernama Sie Djoen Nio, istri Tee Siem Tat. Sebelum suaminya mengenal kekristenan, ia sudah lebih dahulu belajar kekristenan. Sie pernah diberi Alkitab oleh Bibinya yang tinggal di Yogyakarta. Alkitab itu dibaca rutin. Ada kisah yang mengesankan buatnya, sehingga dia menangis ketika membaca, yaitu kisah penderitan dan penyaliban Tuhan Yesus. ${ }^{74}$

\section{KESINAMBUNGAN GERAKAN MISI ANABAPTIS: SINTESA DAN CATATAN KRITIS}

Keyakinan Mennonite akan Yesus sebagai pusat iman menunjukan bahwa gerakan Anabaptis selalu konsisten dalam meneladan Yesus Kristus. Komitmen untuk mengikut Yesus menjadi motif sentral bagi kaum Anabaptis. Seperti ditegaskan oleh Hans Denck, “Tidak ada seorang pun dapat mengenal Kristus kecuali ia mengikuti Dia dalam kehidupan". ${ }^{75}$ Penyataan Denck ini kemudian dipakai oleh Sinode GKMI sebagai komitmen pemuridan dan diikrarkan dalam liturgi ibadah yang berbunyi, "Kami

74 Yudha Lelana, Tunas Yang Tumbuh: Sejarah Gereja Kristen Muria Indonesia 1920-1977, 35.

75 Kalimat ini di rumuskan oleh Hans Denck, seorang Anabaptist Swiss. Rumusan ini kemudian menjadi pengakuan komitmen pemuridan jemaat Mennonite di seluruh dunia dan terdapat dalam liturgi yang diucapkan sebelum Pengakuan Iman Rasuli. Stuart Murray, The Naked Anabaptist: Anabaptis yang Telanjang (Semarang: Pustaka Muria, 2009), 67. bersaksi bahwa tidak seorangpun dapat sunguh-sungguh mengikut Kristus, kecuali ia yang mengikutiNya setiap hari dalam kehidupan." "76 Gereja adalah perantara Allah untuk menyampaikan keselamatan dengan menyerukan pertobatan kepada manusia, supaya kembali kepada Allah. Kristus telah datang kepada semua orang. Keselamatan yang telah diterima tidak hanya berhenti kepada pribadimanusia, tetapimenggerakkan orang untuk mentransformasi dunia. Allah memberikan keselamatan kepada manusia; dan itu berimplikasi pada pemulihan hubungan antar sesama. Baptisan adalah suatu bukti seseorang sudah mengaku percaya bahwa Yesus Kristus adalah Tuhan dan Juru selamat. Iman beroperasi dalam kehidupan manusia.

Misi sebagai Penginjilan menunjukkan bahwa iman mewujud nyata dalam perilaku hidup. Mengutamakan sikap damai, rasa solidaritas kepada orang-orang yang lemah, menjaga keutuhan ciptaan, dan kebebasan memilih mengikut Yesus adalah wujud nyata dari iman Kristen. Motif dari semua itu ialah mengenalkan Kristus kepada orang.

Keterlibatan aktif semua jemaat Mennonite dalam pelayanan dan misi adalah bagian dari hidup orang Kristen. Komunitas-komunitas Mennonite memandang semua orang memiliki martabat sama. Memberitakan Injil Keselamatan merupakan kewajiban semua umat Allah. Di dalam komunitas, orang-orang membangun dan saling menguatkan. Bentuk ini selaras dengan Misi sebagai Pelayanan oleh seluruh umat Allah.

Dalam semua itu, penulis memberikan catatan yang perlu diperhatikan. Pertama,

\footnotetext{
76 Lih. Tim Liturgi Sinode GKMI, Buku Liturgi Sinode GKMI, (Semarang: Pustaka Muria, 2015).
} 
Gereja Mennonite sekarang ini berada di tengah-tengah masyarakat majemuk dan menjadi bagian dunia global. Pengaruh globalisasi tidak bisa dihindari. Pengaruh ini dapat membawa pada krisis identitas atau sebaliknya semakin memperkuat identitasnya untuk dipertahankan. Identitas Mennonite yang mengakui Alkitab sebagai otoritas tertinggi dan Kristus sebagai pusat iman seharusnya membawa orang kepada komitmen untuk mengikutinya. Dalam hal ini, Gereja Mennonite perlu berdialog dengan agama dan kelompok lain guna mentransformasi Gereja dan manusia.

Kedua, kaum Anabaptis awal memiliki pengalaman sejarah sebagai kelompok marginal yang dianiaya oleh gereja resmi dan negara. Pengalaman ini setidaknya memunculkan pendapat yang berbeda mengenai keterlibatan di dalam pemerintahan. Pendapat pertama dari Michael Sattler dan pernyataan Schleitheim melarang keterlibatan orang-orang Anabaptist terlibat dalam pemerintahan. Pendapat ini dilatar belakangi pemikiran karena pemerintah menghalalkan pemakian senjata dan kekerasan dalam menegakkan aturan. ${ }^{77}$ Pendapat kedua dari Pilgram Marpeck. Ia memandang negara secara positif dan mengijinkan kaum Anabaptis terlibat dalam pemerintahan. Terkait dengan pelayanan tersebut, ia mengajarkan bahwa orang-orang Kristen yang masuk dalam pemerintahan dilarang ikut terlibat dalam penggunaan senjata dan masuk ke dalam pelayanan sebagai tentara. ${ }^{78}$ Pendapat dari Marpeck relevan bagi situasi sekarang ini. Jemaat-jemaat Mennonite hidup di tengah-tengah masyarakat yang memberi

\footnotetext{
77 http://www.anabaptistwiki.org/mediawiki/index.php/ Schleitheim_Confession_(source)\#We_have_been_united_as_ follows_concerning_the_sword; diunduh pada 23 Juli 2021

78 Walter Klaassen and William Klassen, Marpeck : a life of dissent and conformity, (Scottdale: Herald Press, 2008), 159
}

ruang pada kebebasan beragama. Perlu dipertimbangkan lagi akan keterlibatan orang-orang dalam kemajuan suatu negara, sejauh itu tidak dilibatkan sebagai alat-alat kekerasan negara. Gereja Mennonite perlu memandang peran negara lebih positif. Sikap damai perlu dikedepankan karena itu letak keradikalan dari ajaran dan identitas kaum Anabaptis Mennonite. Sejak awal sampai hari ini, mereka adalah kelompok yang secara konsisten selalu berusaha mengedepankan pacifisme sebagai bentuk ketaatan pada Yesus Kristus dan sebagai jati diri.

\section{PENUTUP}

Misi Anabaptis tidak dapat dilepaskan dari tiga nilai pokok yang mereka hidupi. Mereka berkomitmen melakukan nilainilai itu sejak abad keenam belas sampai dengan Mennonite di Indonesia sekarang ini. Yesus Kristus, Kitab Suci, dan mengusahakan perdamaian menjadi keutamaan yang harus diberitakan. Karya misi Anabaptist mencakup dimensi rohani dan jasmani. Keselamatan manusia tidak hanya ditujukan kepada kehidupan setelah manusia mati, tetapi juga kepada hidup manusia di dunia ini. karya misi dilakukan melalui tindakan nyata yang menyentuh masyarakat luas, dalam bidang pendidikan, kesehatan, ekonomi, kemanusiaan, dan menjaga perdamaian. Cakupan misi yang sangat luas ini mengharuskan keterlibatan aktif seluruh umat Allah. Dunia yang terus berubah berdampak pada dinamika kehidupan bergereja. Oleh karena itu caracara lama yang tidak lagi sesuai harus mulai diperbaharui, sehingga Injil dapat disampaikan dan diterima oleh sebanyak mugkin orang. 
Misi berarti diutus untuk memanggil orang-orang untuk menjadi murid Yesus. Menjadi murid dimulai dari pertobatan yang mentransformasi seluruh hidup seseorang. Hidup yang berkualitas menjadi faktor utama yang harus dimiliki oleh murid-murid Yesus. Dari sini tampak bahwa misi berlaku secara universal, baik kepada orang-orang Kristen dan orang-orang bukan Kristen. Misi kepad orang-orang Kristen ialah membawa orang-orang Kristen kembali kepada Ajaran

\section{DAFTAR PUSTAKA}

Becker, Palmer. "What is an Anabaptist Christian?" Misio Dei 18. Elkhart: Mennonite Mission Network, 2015

Bosch, David J. Transforming Mission: Paradigm Shifts in Theology of Mission. Maryknoll: Orbis Books, 1991.

Braght, Thieleman J. van. The Bloody Theater or Martyr Mirror of The defenseless Christians [E-Book]. Grand Rapids, MI: Christian Classics Ethereal Library, 1660.

Dyck, Cornelius J.(Ed.). An Introducing To Mennonite History, Cetakan kesembilan. Scottdale: Herald Press, 1979.

Estep, William R. The Anabaptist Story. Grand Rapids, Michigan: William B. Eerdmans Publishing Company, 1975.

Hoekema, Alle. Globalisasi Misi Mulai Abad ke19 (Hubungan Gereja-Gereja Mennonit di Negeri Belanda dengan Indonesia. Semarang: SINODE GKMI, 2002.

Jedin, Hubert (Ed.). History of The Church Volume V. London: Burn \& Oates, 1980.

Klaassen, Walter dan Klassen, William. Marpeck : a life of dissent and conformity, Scottdale: Herald Press, 2008.

Krahn, Cornelius. Dutch Anabaptist Origin, Spread, Life and Thought (1450-1600), Netherlands. The Hague: Martinus Nijhoff, 1968.

Lapp, Johnn A. dan Snyder, C. Arnold. ( ed.). Testing Faith andTradition. Kitchener, Ontario: Pandora Press, 2006.
Yesus. Misi kepada orang-orang bukan Kristen, yaitu usaha memperkenalkan Yesus kristus secara nyata melalui tindakan. Adapun multiplikasi jumlah orang kristen dan penanam gereja bukan menjadi tujuan utama. Keduanya merupakan hasil lain dari misi. Jangkauan yang luas dan menyeluruh perlu menjalin dialog dan kerja sama dengan pihak-pihak lain seperti kelompok-kelompok religius, masyarakat, dan negara.

Lelana, Yudha. Tunas Yang Tumbuh: Sejarah Gereja Kristen Muria Indonesia 1920-1977. Semarang: SINODE GKMI, 2002.

Listijabudi, Daniel K. Spiritualitas Anabaptis. Semarang: Pustaka Muria, Sinode GKMI, 2018.

Murray, Stuart. Anabaptis yang Telanjang: Halhal Hakiki yang Nyata dari Sebuah Iman yang Radikal. Semarang: Pustaka Muria, 2012.

Oyer, John S. dan Kreider, Robert S., Cermin Para Martir, Semarang: Pustaka Muria, 1999.

Schaff, Philip. History of the Christian Church, Volume VIII: Modern Christianity. The Swiss Reformation. Grand Rapids, MI: Christian CLassics Ethereal Library, 1882.

Shenk, Wilbert R. (ed.). Anabaptism and Mission. Scottdale: Herald Press, 1984.

Snyder, Arnold C. Anabaptist History and Theology: An Introduction. Kitcher, Ontario: Pandora Press, 1995.

Dari Benih Anabaptis: Intisari Kesejarahan Jati Diri Anabaptis, Semarang: Pustaka Muria, 2007.

Snyder, C. Arnold dan Hecht, Linda A. Huebert (Eds.). Profiles of Anabaptist Women Sixteenth-Century Reforming Pioneers. Waterloo, Ontario: Wilfrid Laurier University Press, 1996.

Soekotjo, Sigit Heru dan Yoder, Lawrence M. Tata Injil di Bumi Muria: Sejarah Gereja Injili di 
Tanah Jawa-GITJ. Semarang: Pustaka Muria, 2010.

Suyanto, Agus dan Hartono, Paulus, Laskar dan Mennonite: Perjumpaan Islam-Kristen untuk Perdamaian di Indonesia. Jakarta: BPK Gunung Mulia, 2016.

Tim Liturgi Sinode GKMI, Buku Liturgi Sinode GKMI, Semarang: Pustaka Muria, 2015.

Weaver-Zercher, David L., Martyrs mirror: a social history. Baltimore: Johns Hopkins University Press, 1960.

Weaver, J. Denny. Becoming Anabaptist. Scottdale: Herald Press, 1987.

\section{Artikel:}

Kottelin-Longley, M. "What shall I do? The more I kill the greater becomes their number!": the suppression of Anabaptism in early sixteenth century. Scripta Instituti Donneriani Aboensis, 19 (2006): 185 [jurnal online]; tersedia dari https://journal.fi/scripta/article/ view/67308; diakses 8 April 2021.

Listijabudi, Daniel K., "Bianglala Kemuridan Mennonite", Berita GKMI, No. 616, Januari, 2019.

https://journal.fi/scripta/article/view/67308; diakses 8 April 2021.

http://www.internationalbulletin.org/ issues/1999-01/1999-01-026-livingston.pdf diunduh pada 20 April 2021.

https://gameo.org/index.php?title=Mennonite Central_Committee_(International) diakses pada $27^{-}$April 2021.

http://www.anabaptistwiki.org/mediawiki/index. php/Schleitheim_Confession_(source)\#We have_been_united_as_follows_concerning_the_sword; diunduh pada 23 Juli 2021 
